\title{
Pharmacokinetics and Biodistribution of Zinc-Enriched Yeast in Rats
}

\author{
Shuangqing Zhang, ${ }^{1,2}$ Yan Zhang, ${ }^{1}$ Ning Peng, ${ }^{1}$ Haibo Zhang, \\ Juan Yao, ${ }^{1}$ Zhihong Li, ${ }^{1}$ and Liegang Liu ${ }^{2}$ \\ ${ }^{1}$ Division of Nutrition and Health, Angel Yeast Co. Ltd., 168 Chengdong Avenue, Yichang 443003, China \\ ${ }^{2}$ Department of Nutrition and Food Hygiene, Hubei Key Laboratory of Food Nutrition and Safety, \\ State Key Laboratory of Environment Health (Incubation), School of Public Health, Tongji Medical College, \\ Huazhong University of Science and Technology, Wuhan 430030, China
}

Correspondence should be addressed to Liegang Liu; lgliu@mails.tjmu.edu.cn

Received 21 July 2014; Revised 3 August 2014; Accepted 7 August 2014; Published 17 August 2014

Academic Editor: Feng Sun

Copyright ( 2014 Shuangqing Zhang et al. This is an open access article distributed under the Creative Commons Attribution License, which permits unrestricted use, distribution, and reproduction in any medium, provided the original work is properly cited.

\begin{abstract}
Zinc-enriched yeast $(\mathrm{ZnY})$ and zinc sulfate $\left(\mathrm{ZnSO}_{4}\right)$ are considered zinc $(\mathrm{Zn})$ supplements currently available. The purpose of the investigation was to compare and evaluate pharmacokinetics and biodistribution of $\mathrm{ZnY}$ and $\mathrm{ZnSO}_{4}$ in rats. $\mathrm{ZnY}_{\text {or }} \mathrm{ZnSO}_{4}$ were orally administered to rats at a single dose of $4 \mathrm{mg} \mathrm{Zn} / \mathrm{kg}$ and $\mathrm{Zn}$ levels in plasma and various tissues were determined using inductively coupled plasma-optical emission spectrometry. Maximum plasma concentration values were 3.87 and $2.81 \mu \mathrm{g} / \mathrm{mL}$ for $\mathrm{ZnY}$ and $\mathrm{ZnSO}_{4}$, respectively. Both $\mathrm{ZnY}$ and $\mathrm{ZnSO}_{4}$ were slowly eliminated with a half-life of over $7 \mathrm{~h}$ and bone had the highest $\mathrm{Zn}$ level in all tissues. Compared to $\mathrm{ZnSO}_{4}$, the relative bioavailability of $\mathrm{ZnY}$ was $138.4 \%$, indicating that $\mathrm{ZnY}$ had a significantly higher bioavailability than $\mathrm{ZnSO}_{4}$.
\end{abstract}

\section{Introduction}

Essential trace elements are very important for the proper functioning of living organisms, such as growth and maintenance, neuromodulation, and regulation of cellular function, and thus their deficiency is associated with an enormous health risk that can ultimately lead to death [1]. Zinc (Zn) is an essential trace element for plants, microorganisms, animals, and humans and plays numerous central roles in structure and function of proteins, metabolism of RNA and DNA, signal transduction, gene expression, and regulation of apoptosis [2]. Zn deficiency affects nearly two billion people in the developing countries and is associated with many diseases, including depressed growth, diarrhea, impotence and delayed sexual maturation, alopecia, eye and skin lesions, impaired appetite, altered cognition, impaired host defense properties, defects in carbohydrate utilization, and reproductive teratogenesis $[3,4]$. Zn deficiency is usually caused by insufficient dietary intake but can be associated with many diseases, such as malabsorption, acrodermatitis enteropathica, chronic liver disease, chronic renal disease, sickle cell disease, diabetes, malignancy, and other chronic illnesses [4]. Zn supplements help prevent disease and reduce mortality, especially among children with low birth weight or stunted growth. $\mathrm{Zn}$ supplements include $\mathrm{Zn}$ chloride and $\mathrm{Zn}$ sulfate $\left(\mathrm{ZnSO}_{4}\right)$ as inorganic salts for parenteral administration, $\mathrm{Zn}$ gluconate, $\mathrm{Zn}$ gluconate/glycine, $\mathrm{Zn}$ acetate, and $\mathrm{Zn}$ propionate as salts of organic acids for oral usage, and $\mathrm{Zn}$ enriched yeast $(\mathrm{ZnY})$ or $\mathrm{Zn}$-enriched grains as biologically organic forms for oral intake [5].

$\mathrm{ZnY}$, a biological source of $\mathrm{Zn}$ with rich proteins, peptides, and amino acids, is naturally integrated by the growing yeast into its own structure to improve the bioavailability of $\mathrm{Zn}$ and reduce the side effects of $\mathrm{Zn}$. $\mathrm{ZnY}$ is used as the raw material of foods, functional foods, and medicines, such as dairy products, biscuits, beverages, and flour. So far, only 
two studies of $\mathrm{ZnY}$ reported that $\mathrm{ZnY}$ was more bioavailable than $\mathrm{Zn}$ gluconate in rat liver and human $[6,7]$. The purpose of the present investigation was to compare and evaluate pharmacokinetics and biodistribution of $\mathrm{ZnY}$ and $\mathrm{ZnSO}_{4}$ in rats.

\section{Materials and Methods}

2.1. Materials. ZnY was provided by Angel Yeast Co. Ltd. (Yichang, Hubei, China). $\mathrm{ZnSO}_{4}$ was obtained from Sigma Aldrich (St. Louis, MO, USA). Nitric acid and perchloric acid were the guaranteed reagents. All other reagents were of analytical grade and obtained through commercial sources.

2.2. Pharmacokinetics and Biodistribution. All procedures involving animals were approved by our Institutional Animal Care and Use Committee. Adult Sprague-Dawley rats, weighing $250 \pm 11 \mathrm{~g}$, were obtained from Jackson Laboratory (Bar Harbor, ME, USA) and housed in standard cages and allowed free movement and access to food and water during the whole experiment. The rats were randomly assigned into two groups and orally given either $\mathrm{ZnY}$ or $\mathrm{ZnSO}_{4}$ at a single dose of $4 \mathrm{mg} \mathrm{Zn/kg}$. At designated time-points, blood was collected in a heparin-coated tube and plasma was separated by centrifugation at $5,000 \mathrm{~g}$ for $10 \mathrm{~min}$. Supernatant was then transferred to a clean tube and immediately stored at $-80^{\circ} \mathrm{C}$ until analysis. Immediately after the last time-point blood collection, rats were sacrificed using carbon dioxide and tissues (liver, heart, pancreas, spleen, kidney, and bone) were immediately excised. All tissue samples washed with tridistilled water were frozen at $-80^{\circ} \mathrm{C}$ until analysis.

2.3. Zn Determination. $\mathrm{Zn}$ levels in plasma, liver, heart, pancreas, spleen, kidney, and bone were determined using inductively coupled plasma-optical emission spectrometry (Model 720, Agilent Inc., CA, USA). Samples were prepared as follows: $100 \mu \mathrm{L}$ of plasma or weighted tissue specimen was pretreated with the mixture of nitric acid and perchloric acid $(20: 1, \mathrm{v} / \mathrm{v})$ overnight and heated at the temperature of $180-$ $200^{\circ} \mathrm{C}$ until samples were completely digested, that is, until the solutions were colorless and clear. The remaining acid solution was cooled and diluted with tridistilled water to an appropriate concentration for the assay. Quality control samples were employed for the validation of analytical method and the analytical error was less than $11 \%$.

2.4. Data Analysis. Pharmacokinetic parameters of $\mathrm{ZnY}$ and $\mathrm{ZnSO}_{4}$ were calculated using noncompartmental analysis of WinNonlin software (Version 5.2.1, Pharsight Corp., Mountain View, CA, USA). Results are presented as mean \pm standard deviation (SD). The comparison for difference between parameters or between groups was analyzed using one-way analysis of variance (ANOVA). Differences were considered statistically significant at $P<0.05$.

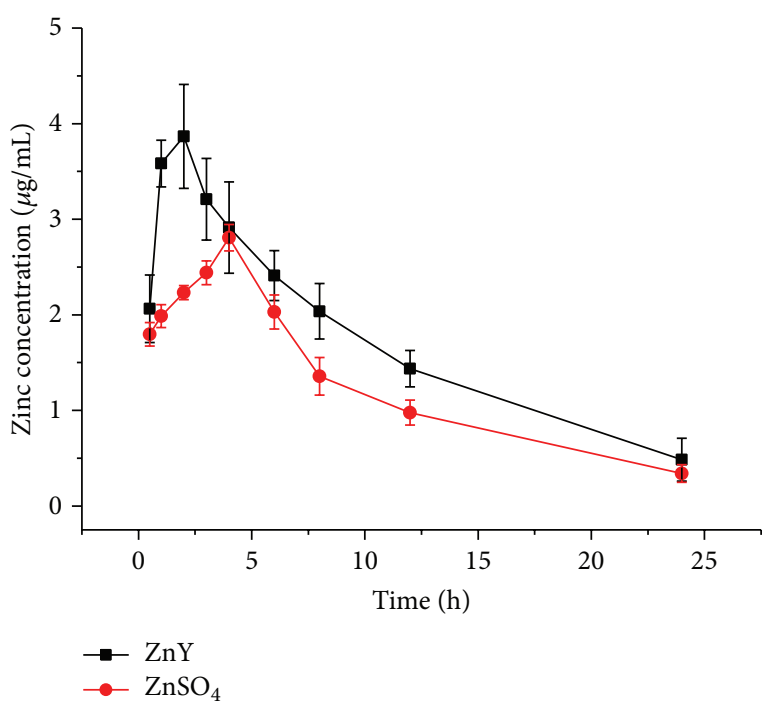

FIGURE 1: The mean plasma concentration-time profiles of $\mathrm{ZnY}$ and $\mathrm{ZnSO}_{4}$ after a single oral administration of zinc compounds at a dose level of $4 \mathrm{mg} \mathrm{Zn} / \mathrm{kg}(n=3)$.

\section{Results and Discussion}

Although food is the major source of $\mathrm{Zn}$, low $\mathrm{Zn}$ content in diet and many adverse nutritional factors are barriers to prevention and treatment of $\mathrm{Zn}$ deficiency $[8,9]$. Zn chloride, $\mathrm{ZnSO}_{4}$, and $\mathrm{Zn}$ oxide are often employed for food fortification; however there are serious shortcomings for those compounds. $\mathrm{Zn}$ chloride causes some adverse effects, $\mathrm{ZnSO}_{4}$ renders unpalatable flavor, and water-insoluble $\mathrm{Zn}$ oxide precipitates in liquid foods; therefore, those compounds are used only in low quantities and in solid foods. ZnY has high solubility and a soft taste, and it does not modify the sensorial characteristics of food.

The concentration-time profile of $\mathrm{ZnY}$ and $\mathrm{ZnSO}_{4}$ in plasma is shown in Figure 1 and their pharmacokinetic parameters are listed in Table 1. Peak plasma concentration $\left(C_{\max }\right)$ and the time to reach $C_{\max }\left(T_{\max }\right)$ were $3.87 \mu \mathrm{g} / \mathrm{mL}$ and $2 \mathrm{~h}$ for $\mathrm{ZnY}$ and $2.81 \mu \mathrm{g} / \mathrm{mL}$ and $4 \mathrm{~h}$ for $\mathrm{ZnSO}_{4}$, respectively. $C_{\text {max }}, \mathrm{AUC}_{0-24 \mathrm{~h}}$, and $\mathrm{AUC}_{0-\infty}$ ratio values of $\mathrm{ZnY}$ to $\mathrm{ZnSO}_{4}$ were $137.7 \%, 138.4 \%$, and $139.2 \%$, respectively, indicating that $\mathrm{ZnY}$ had a significantly higher bioavailability than $\mathrm{ZnSO}_{4}$. Both $\mathrm{ZnY}$ and $\mathrm{ZnSO}_{4}$ were slowly eliminated in vivo with respective $t_{1 / 2, \lambda z}$ values of 7.68 and $7.93 \mathrm{~h}$. During $\mathrm{ZnY}$ fermentation in the presence of $\mathrm{Zn}$ chloride or $\mathrm{ZnSO}_{4}$, a specific strain of yeast produced specific zinc compounds conjugated with proteins, peptides, and amino acids, which helped improve bioavailability of $\mathrm{ZnY}$ compared to inorganic $\mathrm{Zn}$ via enhanced intestinal absorption. Our findings with $\mathrm{ZnY}$ are consistent with previous studies in which animal proteins could improve $\mathrm{Zn}$ absorption $[6,10]$, which could physiologically illustrate protein as the major dietary source of $\mathrm{Zn}$.

Zn levels in liver, heart, pancreas, spleen, kidney, and bone are presented in Figure 2. The biodistribution results demonstrated that $\mathrm{Zn}$ was widely distributed in various rat 
TABLE 1: The pharmacokinetic parameters of $\mathrm{ZnY}$ and $\mathrm{ZnSO}_{4}$ after a single oral administration of $\mathrm{Zn}$ compounds at a dose level of $4 \mathrm{mg}$ $\mathrm{Zn} / \mathrm{kg}$. Values are presented as mean $\pm \mathrm{SD}(n=3)$.

\begin{tabular}{lccc}
\hline Parameter & Unit & $\mathrm{ZnY}$ & $\mathrm{ZnSO}_{4}$ \\
\hline$t_{1 / 2, \lambda z}$ & $\mathrm{~h}$ & $7.68 \pm 1.82$ & $7.93 \pm 0.87$ \\
$\mathrm{AUC}_{0-24 \mathrm{~h}}$ & $\mathrm{~h} \cdot \mu \mathrm{g} / \mathrm{mL}$ & $40.49 \pm 5.48$ & $29.26 \pm 3.01$ \\
$\mathrm{AUC}_{0-\infty}$ & $\mathrm{h} \cdot \mu \mathrm{g} / \mathrm{mL}$ & $46.24 \pm 8.97$ & $33.22 \pm 4.43$ \\
$V$ & $\mathrm{~mL} / \mathrm{kg}$ & $954 \pm 77$ & $1381 \pm 50$ \\
$\mathrm{Cls}$ & $\mathrm{mL} / \mathrm{h} / \mathrm{kg}$ & $88.8 \pm 17.7$ & $121.9 \pm 17.0$ \\
$\mathrm{MRT}_{0-24 \mathrm{~h}}$ & $\mathrm{~h}$ & $7.94 \pm 0.56$ & $7.84 \pm 0.36$ \\
$\mathrm{MRT}_{0-\infty}$ & $\mathrm{h}$ & $11.20 \pm 2.31$ & $11.09 \pm 1.25$
\end{tabular}

$t_{1 / 2, \lambda z}$ : terminal half-life; $\mathrm{AUC}_{0-24 \mathrm{~h}}$ : area under curve from 0 to $24 \mathrm{~h}$; $\mathrm{AUC}_{0-\infty}$ : area under curve from 0 to infinite time; Cls: systemic clearance; $V$ : volume of distribution; $\mathrm{MRT}_{0-24 \mathrm{~h}}$ : mean residence time from 0 to $24 \mathrm{~h}$; $\mathrm{MRT}_{0-\infty}$ : mean residence time from 0 to infinite time.

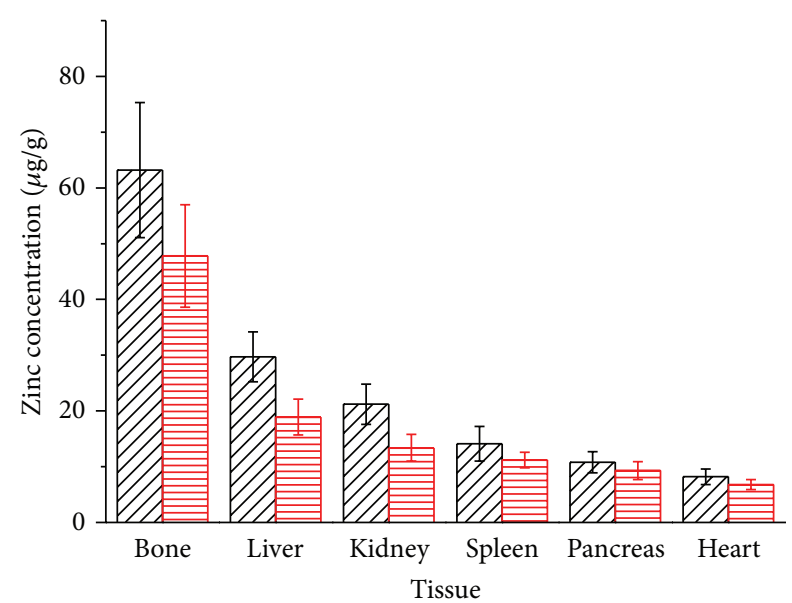

Z77 ZnY

$\rightleftharpoons \mathrm{ZnSO}_{4}$

Figure 2: Distribution profiles of $\mathrm{ZnY}$ and $\mathrm{ZnSO}_{4}$ in rat tissues at $24 \mathrm{~h}$ after a single oral administration of zinc compounds at a dose level of $4 \mathrm{mg} \mathrm{Zn} / \mathrm{kg}(n=3)$.

tissues after oral administration of $\mathrm{ZnY}$ and $\mathrm{ZnSO}_{4}$ in which bone had the highest $\mathrm{Zn}$ level, and $\mathrm{ZnY}$ showed higher $\mathrm{Zn}$ level than $\mathrm{ZnSO}_{4}$ in each tissue. The results are in agreement with previous report [11]. $\mathrm{Zn}$ is essential for bone mineralization and bound to the mineral matrix. Bone growth retardation is usually associated with $\mathrm{Zn}$ deficiency [12]. $\mathrm{Zn}$ can stimulate proliferation, differentiation, and protein synthesis in osteoblastic cells and inhibit the formation of osteoclastic cells from bone marrow cells [13-15]; therefore $\mathrm{Zn}$ plays an important role in the preservation of bone mass by stimulating bone formation and inhibiting bone resorption. Despite the lower $\mathrm{Zn}$ levels in tissues other than bone, $\mathrm{Zn}$ metalloenzymes are widespread throughout body organs and play crucial roles in many physiologic processes. Other organs that had significant $\mathrm{Zn}$ concentration were liver, kidney, spleen, and pancreas; liver, spleen, and pancreas are closely associated with $\mathrm{Zn}$ metabolism while kidney is related with $\mathrm{Zn}$ excretion. Small intestine is the major absorption organ of $\mathrm{Zn}$, and a part of absorbed $\mathrm{Zn}$ is stored bound to intestinal metallothionein, while the rest of $\mathrm{Zn}$ is transported by blood albumin and bound to hepatic metallothionein in liver or involved in a wide range of metabolic functions in many tissues [11].

\section{Conclusions}

In conclusion, $\mathrm{Zn}$ from $\mathrm{ZnY}$ was more bioavailable than zinc from inorganic zinc salts $\mathrm{ZnSO}_{4}$; disposition and biodistribution of $\mathrm{Zn}$ in $\mathrm{ZnY}$ were similar to those of other sources of Zn.

\section{Conflict of Interests}

The authors declare that there is no conflict of interests regarding the publication of this paper.

\section{Authors' Contribution}

Shuangqing Zhang and Yan Zhang contributed equally to this work.

\section{References}

[1] K. Mlyniec, C. L. Davies, I. G. de Aguero, K. Sanchez, B. Budziszewska, and G. Nowak, "Essential elements in depression and anxiety. Part I," Pharmacological Reports, vol. 66, no. 4, pp. 534544, 2014.

[2] K. M. Hambidge and N. F. Krebs, "Zinc deficiency: a special challenge," Journal of Nutrition, vol. 137, no. 4, pp. 1101-1105, 2007.

[3] United States National Research Council, Institute of Medicine, Dietary reference intakes for vitamin a, vitamin $k$, arsenic, boron, chromium, copper, iodine, iron, manganese, molybdenum, nickel, silicon, vanadium, and zinc, National Academies Press, Washington, DC, USA, pp. 442-445, 2000.

[4] A. S. Prasad, "Zinc deficiency," The British Medical Journal, vol. 326, no. 7386, pp. 409-410, 2003.

[5] R. A. DiSilvestro, Handbook of Minerals as Nutritional Supplements, CRC Press, 2004.

[6] T. A. Tompkins, N. E. Renard, and A. Kiuchi, "Clinical evaluation of the bioavailability of zinc-enriched yeast and zinc gluconate in healthy volunteers," Biological Trace Element Research, vol. 120, no. 1-3, pp. 28-35, 2007.

[7] J. A. Vinson, T. A. Tompkins, and G. A. Agbor, "Comparative bioavailability of mineral-enriched gluconates and yeast in rat liver after depletion-repletion feeding," Biological Trace Element Research, vol. 118, no. 2, pp. 104-110, 2007.

[8] H. H. Sandstead and J. C. Smith Jr., "Deliberations and evaluations of approaches, endpoints and paradigms for determining zinc dietary recommendations," Journal of Nutrition, vol. 126, no. 9, pp. 2410S-2418S, 1996.

[9] B. Sandstrom, A. Almgren, B. Kivisto, and A. Cederblad, "Effect of protein level and protein source on zinc absorption in humans," Journal of Nutrition, vol. 119, no. 1, pp. 48-53, 1989.

[10] F. Cámara and M. A. Amaro, "Nutritional aspect of zinc availability," International Journal of Food Sciences and Nutrition, vol. 54, no. 2, pp. 143-151, 2003. 
[11] M. J. Salgueiro, M. B. Zubillaga, A. E. Lysionek et al., "Bioavailability, biodistribution, and toxicity of BioZn-AAS: a new source: comparative studies in rats," Nutrition, vol. 16, no. 9, pp. 762-766, 2000.

[12] A. S. Prasad, "Laboratory diagnosis of zinc deficiency," Journal of the American College of Nutrition, vol. 4, no. 6, pp. 591-598, 1985.

[13] M. Hashizume and M. Yamaguchi, "Stimulatory effect of $\beta$ alanyl-L-histidinato zinc on cell proliferation is dependent on protein synthesis in osteoblastic MC3T3-E1 cells," Molecular and Cellular Biochemistry, vol. 122, no. 1, pp. 59-64, 1993.

[14] M. Hashizume and M. Yamaguchi, "Effect of $\beta$-alanyl-Lhistidinato zinc on differentiation of osteoblastic MC3T3-E1 cells: increases in alkaline phosphatase activity and protein concentration," Molecular and Cellular Biochemistry, vol. 131, no. 1, pp. 19-24, 1994.

[15] S. Kishi and M. Yamaguchi, "Inhibitory effect of zinc compounds on osteoclast-like cell formation in mouse marrow cultures," Biochemical Pharmacology, vol. 48, no. 6, pp. 1225-1230, 1994. 

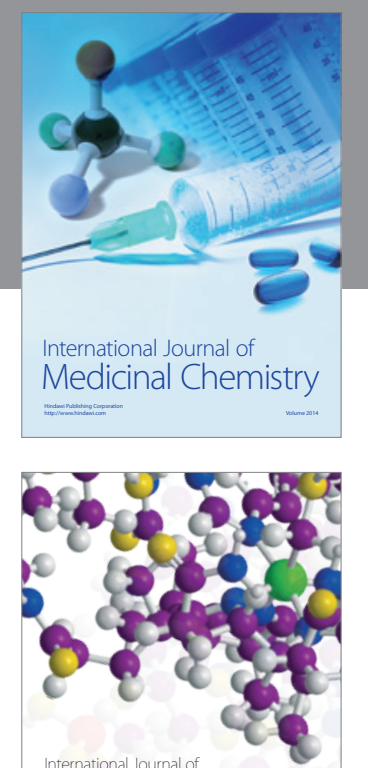

\section{Carbohydrate} Chemistry

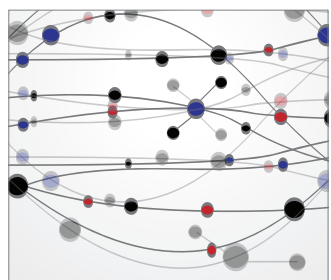

The Scientific World Journal
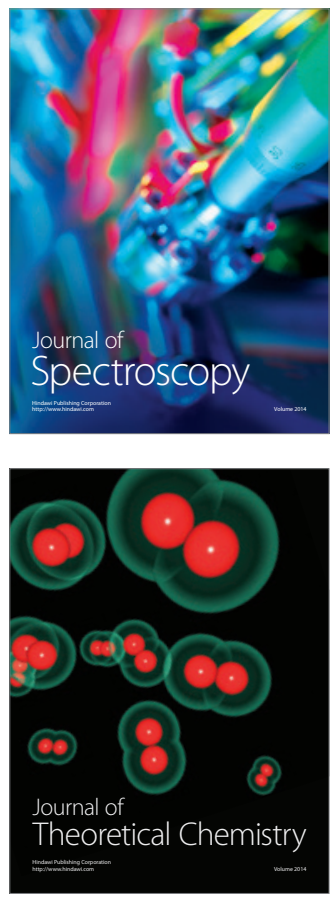
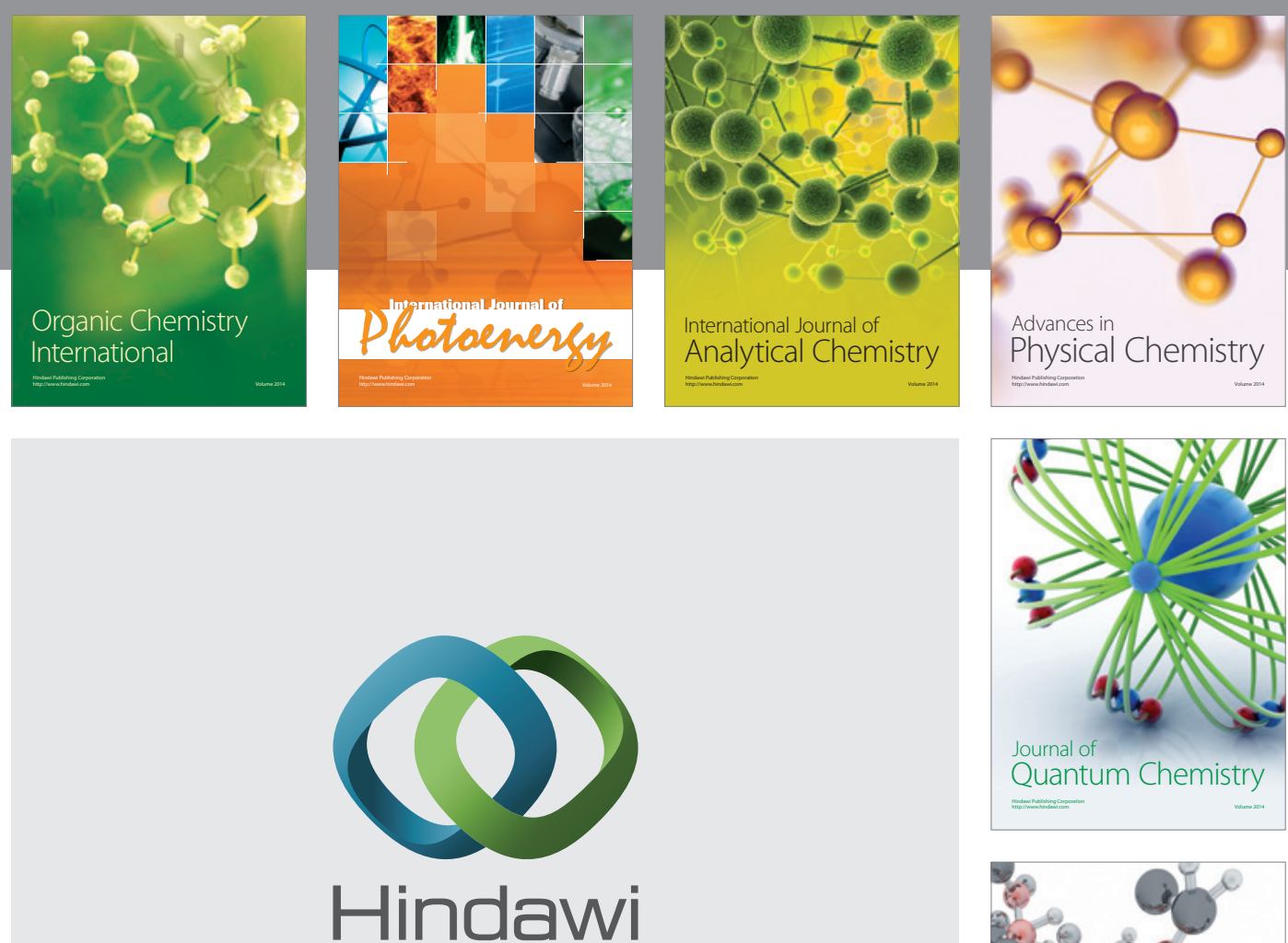

Submit your manuscripts at

http://www.hindawi.com

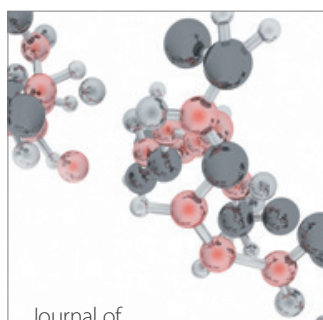

Analytical Methods

in Chemistry

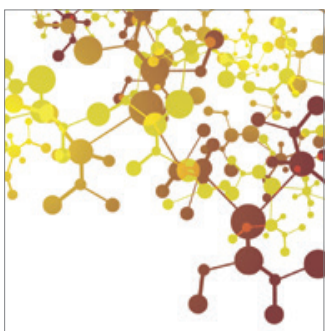

Journal of

Applied Chemistry

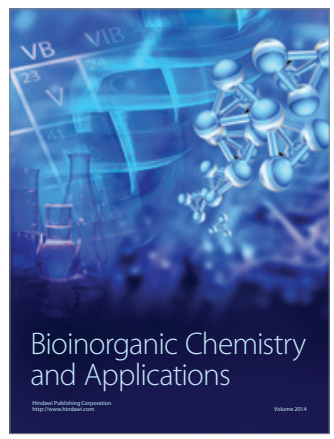

Inorganic Chemistry
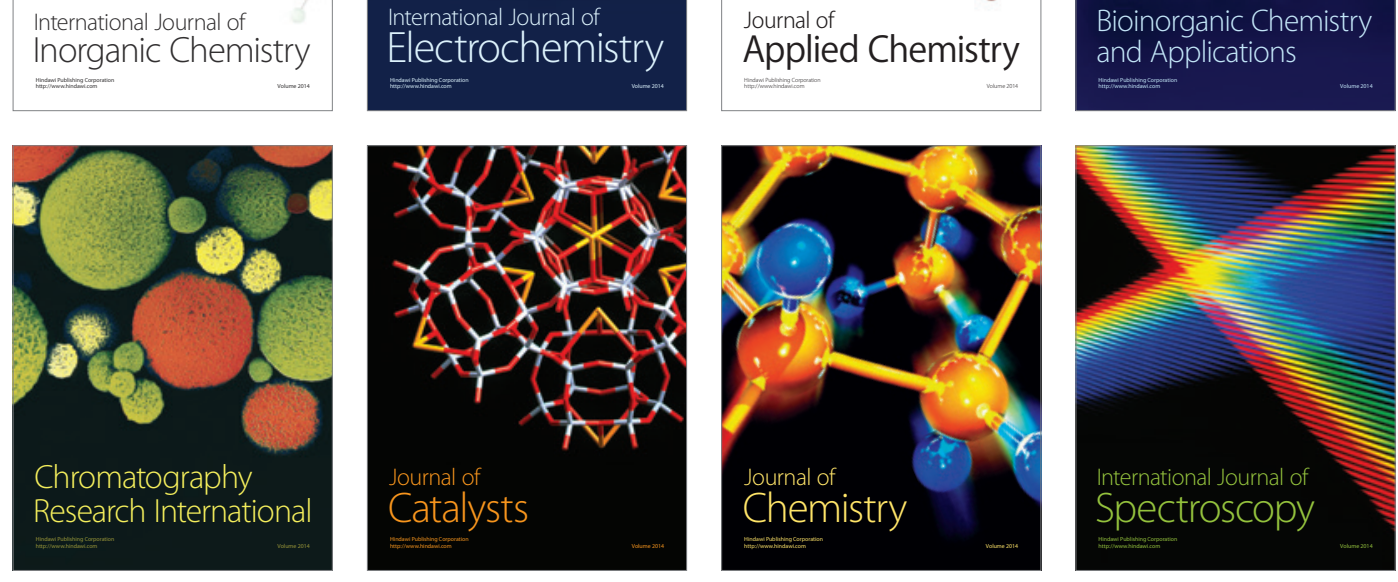